\title{
GETAH POHON KUDO (Lannea coromandelica) SEBAGAI ALTERNATIF PEREKAT UNTUK PRODUK KERAJINAN
}

Kudo (Lannea coromandelica) Sap as an Alternatif Adhesive for Handicraft Products

\author{
Istihanah Nurul Eskani, Arif Perdana, Edi Eskak dan Hadi Sumarto \\ Balai Besar Kerajinan dan Batik \\ istihanah-nurul@kemenperin.go.id \\ Tanggal Masuk: 06 Februari 2017 \\ Tanggal Revisi: 25 April 2017 \\ Tanggal disetujui: 27 April 2017
}

\begin{abstract}
ABSTRAK
Perekat sintetis yang biasa digunakan di industri kerajinan bersumber dari bahan yang tidak dapat diperbaharui (unrenewable). Saat ini banyak dikembangkan pemanfaatan bahan alami sebagai substitusi bahan sintetis, termasuk bahan baku perekat. Penelitian ini bertujuan untuk mengembangkan perekat alami dari getah pohon Kudo (Lannea coromandelica) yang biasa disebut dengan getah blendok. Getah blendok dilarutkan dalam air dengan rasio getah blendok:air = 1:3 kemudian dipanaskan dalam waterbath pada suhu $70^{\circ} \mathrm{C}-80^{\circ} \mathrm{C}$ selama 1 jam. Zat aditif Maleat Anhidrida (MAH) ditambahkan dengan kadar 2,5\%, 5\%, 7,5\% dan 10\% dari berat getah blendok, dengan masing-masing ditambahkan kadar Benzoil Peroksida (BPO) 0,75\%. Perekat yang diperoleh diaplikasikan pada bahan kulit kayu Jomok (Arthocarpus elastica) dan selanjutnya dilakukan uji sifat-sifat fisis dan mekanisnya. Sifat fisis perekat dibandingkan dengan SNI 06-6049-1999 Perekat PVAc sedangkan sifat mekanisnya dibandingkan dengan performa perekat sintetis. Hasil penelitian menunjukkan bahwa sifat-sifat fisis perekat dari getah blendok telah sesuai dengan SNI dan sifat-sifat mekanisnya sebanding dengan performa perekat sintetis yang biasa digunakan di industri kerajinan.
\end{abstract}

Kata kunci: perekat alami, getah, pohon kudo, maleat anhidrida

\begin{abstract}
Synthetic adhesives commonly used in the craft industry is made from unrenewable materials. Currently the utilization of natural materials as substitution of synthetic ones have been developed, including adhesive raw materials. This research aims to develop natural adhesive from Kudo (Lannea coromandelica) tree sap, commonly referred to blendok. Blendok was dissolved in water at a ratio of blendok:water $=1: 3$ and then heated in a water bath at a temperature of $70^{\circ} \mathrm{C}-80^{\circ} \mathrm{C}$ for 1 hour. Maleic Anhydride (MAH) was added to the level of $2.5 \%, 5 \%, 7.5 \%$ and $10 \%$ of the weight of blendok, and Benzoyl Peroxide (BPO) $0.75 \%$ was added in each level. Adhesive was applied to the craft material Jomok (Arthocarpus elastica) tree bark and the physical and mechanical properties was tested. The physical properties of adhesive compared with SNI 06-6049-1999 PVAc adhesive while the mechanical properties compared with the performance of synthetic adhesives. The results showed that the physical properties of the blendok adhesive complies with SNI and its mechanical properties comparable to the performance of synthetic adhesives used in the craft industry.
\end{abstract}

Keywords : natural adhesives, sap, kudo tree, maleic anhydride

\section{PENDAHULUAN}

Perekat merupakan salah satu bahan utama yang sangat penting di industri. Jenis perekat yang umum digunakan adalah perekat sintetis berbasis formaldehida seperti

Urea Formaldehyde (UF), Melamine Formaldehyde (MF) dan Phenol Formaldehyde (PF). Di industri kerajinan, 
perekat sintetis yang biasa digunakan adalah lem kuning dan lem putih (PVAc). Bahan baku perekat ini berasal dari sumber daya alam yang tidak dapat diperbaharui (unrenewable) dan tidak terurai di alam (non biodegradable). Selain itu perekat berbasis formaldehida dapat menimbulkan emisi formaldehida yang menyebabkan gejala pusing, sesak napas dan insomnia (Karliati, 2014). Lem kuning dan lem putih (PVAc) yang biasa digunakan di industri kerajinan tergolong solvent based, menggunakan pelarut organik yang bersumber dari minyak bumi. Pelarut atau solvent merupakan zat kimia yang digunakan untuk mengencerkan bahan lain. Pelarut organik mempunyai potensi bahaya bagi lingkungan kerja karena dapat menimbulkan kebakaran. Oleh karena itu perlu dilakukan penelitian untuk mengembangkan perekat dari bahan-bahan alami terutama yang menggunakan pelarut air (waterbased), sebagai alternatif perekat di industri kerajinan.

Blendok adalah cairan/getah yang keluar dari pohon karena disayat/disadap. Getah blendok merupakan polimer alam yang mengandung senyawa karbohidrat, protein, terpenoid dan polifenol yang berperan penting sebagai perekat (Reddy, 2011). Kata blendok berasal dari bahasa jawa yang kemudian digunakan untuk menyebut getah yang keluar dari pohon Kudo (Lannea coromandelica). Pohon Kudo adalah sejenis pohon yang banyak ditanam di pinggir jalan atau di pekarangan sebagai pagar hidup. Pohon Kudo tersebar luas di Indonesia, di daerah Sulawesi disebut dengan nama Kayu Jawa, di Jawa disebut pohon Kudo, Jaranan, Kedondong Laki, dan di Flores disebut pohon Reo.

Di India, pohon Kudo disebut dengan Indian Ash Tree dan banyak digunakan untuk mengobati berbagai penyakit, antara lain sakit gigi, sakit perut dan impotensi (Reddy,
2011). Getah blendok yang keluar dari pohon kudo ini belum banyak dimanfaatkan. Sebagian masyarakat memanfaatkannya sebagai lem namun masih terbatas karena kesulitan dalam penanganannya.

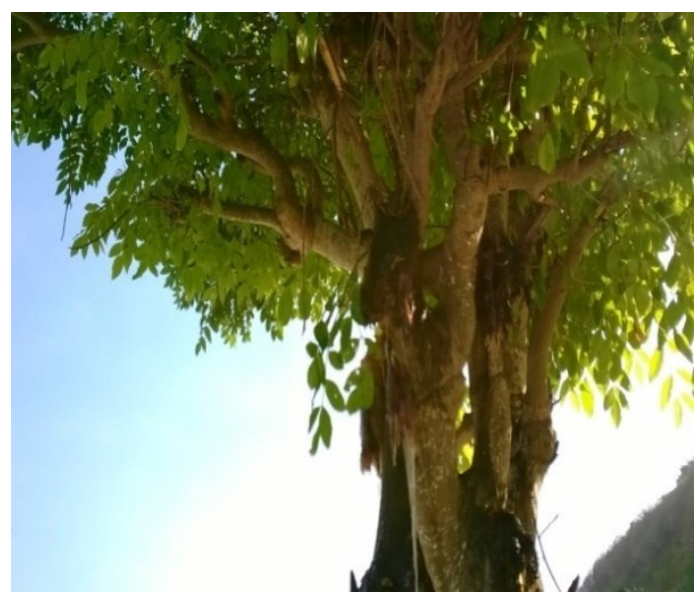

Gambar 1. Pohon kudo (Lannea coromandelica)

Penelitian ini dilakukan untuk mengembangkan perekat dari getah blendok dengan menggunakan pelarut air (waterbased) kemudian diuji sifat fisis dan mekanisnya pada bahan baku kerajinan kulit kayu jomok dan dibandingkan dengan SNI dan perekat sintetis yang biasa digunakan di industri kerajinan. Zat aditif yang ditambahkan dalam penelitian ini adalah Maleic Anhydride (MAH) dan Benzoil Peroxyde (BPO). MAH adalah senyawa vinil tidak jenuh yang merupakan bahan mentah dalam sintesis resin poliester, pelapisan permukaan karet, deterjen, bahan aditif, minyak pelumas, plasticizer dan kopolimer (Adriana, 2001 dalam Fathanah, 2011). Berdasarkan Material Safety Data Sheet (MSDS), MAH dan BPO dapat menimbulkan iritasi pada kulit dan pernapasan apabila kontak terlalu lama namun tidak menimbulkan efek karsinogen dan mutagenik seperti halnya formaldehida. MAH berfungsi sebagai coupling agents yang membantu kompatibilitas antara bahan 
yang direkat dengan perekat. Sedangkan BPO sebagai inisiator selama terjadinya coupling. Penambahan MAH akan menyebabkan terjadinya adhesi atau pencangkokan (grafting) melalui esterifikasi antara matriks polimer dengan gugus hidroksil dari kayu (Febrianto, dkk, 1999)

\section{METODOLOGI PENELITIAN \\ Bahan dan Alat}

Bahan-bahan yang digunakan dalam penelitian ini adalah: getah blendok, zat aditif MAH dan BPO, aquades, kertas $\mathrm{pH}$, kulit kayu jomok, kertas karton, lem sintetis (lem kuning) dan tripleks. Sedangkan alat-alat yang digunakan: neraca digital, waterbath, gelas beker $500 \mathrm{ml}$, pengaduk, pemanas listrik, termometer, viskometer cup and bob, dan piknometer.

\section{Tahapan Penelitian}

\section{Pembuatan Perekat dari Getah Blendok}

Dibuat 4 macam perekat dari getah blendok, yaitu perekat dengan zat aditif MAH $2,5 \%, 5 \%, 7,5 \%$ dan $10 \%$ dari berat getah blendok, dengan masing-masing ditambahkan kadar BPO 0,75\% (Karliati, 2014). Berdasarkan pra penelitian diketahui bahwa zat aditif juga berfungsi sebagai pengawet sehingga apabila tanpa aditif (MAH 0\%) maka perekat tidak awet (berjamur).

Getah blendok ditimbang kemudian dilarutkan dalam air dengan rasio getah blendok:air $=1: 3$ kemudian dipanaskan dalam waterbath pada suhu $70^{\circ} \mathrm{C}-80^{\circ} \mathrm{C}$ selama 1 jam. Zat aditif MAH ditambahkan pada menit ke 45. Setelah 1 jam perekat diangkat dan ditambahkan BPO setelah 12 jam.

\section{Pengujian Sifat-sifat Fisis Perekat}

Sifat-sifat fisis yang diuji meliputi berat jenis, viskositas, dan $\mathrm{pH}$. Hasil pengujian dibandingkan dengan SNI 06-6049-1999 perekat PVAc (BSN, 1999).

\section{Pengujian Sifat-sifat Mekanis Perekat}

Sifat-sifat mekanis yang diuji meliputi kekuatan rekat (peel test) dan delaminasi perekat. Peel test menggunakan standar uji British Standard BS 5350-C12:1994, $180^{\circ}$ peel test for flexible to flexible bonded assemblies (T-Peel Test). Perekat dilaburkan pada kulit kayu jomok dan direkatkan pada kertas karton kemudian dibuat spesimen uji berukuran $25 \mathrm{~mm}$ x $200 \mathrm{~mm}$, bagian yang tidak dilabur perekat sepanjang 50mm (BS, 1994).

Pengujian delaminasi menggunakan standar SNI 01-7201-2006. Spesimen uji dibuat dengan ukuran $75 \mathrm{~mm}$ x $75 \mathrm{~mm}$ pada kulit kayu jomok yang direkatkan pada kayu tripleks. Spesimen uji direndam dalam air panas pada suhu $(35 \pm 3)^{\circ} \mathrm{C}$ selama 2 jam kemudian dikeringkan dalam oven pada suhu $(60 \pm 3)^{\circ} \mathrm{C}$ selama 3 jam (BSN, 2006).

Presentase nilai delaminasi dapat dihitung dengan persamaan 1 .

$\mathrm{D}=\frac{\mathrm{a}}{\mathrm{A}} \times 100 \%$

Keterangan:

$\mathrm{D}=$ Nilai Delaminasi (\%)

$\mathrm{a}=$ Luas bagian yang mengelupas $\left(\mathrm{mm}^{2}\right)$

$\mathrm{A}=$ Luas spesimen uji $\left(\mathrm{mm}^{2}\right)$

\section{HASIL DAN PEMBAHASAN \\ Sifat-sifat Fisis Perekat}

Sifat-sifat fisis perekat ditunjukkan pada Tabel 1. Viskositas perekat menunjukkan kemampuan perekat untuk mengalir dari suatu permukaan ke permukaan yang lain pada bahan yang direkat untuk dapat membentuk suatu lapisan yang kontinu, menyebar merata pada seluruh permukaan (Widiyanto, 2011). 
Tabel 1. Sifat-sifat fisis perekat

\begin{tabular}{ccccc}
$\begin{array}{c}\text { Jenis } \\
\text { perekat }\end{array}$ & $\begin{array}{c}\text { MAH } \\
\text { (\%) }\end{array}$ & $\begin{array}{c}\text { Viskositas } \\
\text { (poise) }\end{array}$ & $\begin{array}{c}\text { Berat } \\
\text { jenis } \\
\left(\mathbf{g} / \mathbf{c m}^{3}\right)\end{array}$ & pH \\
\hline BLML 1 & 2,5 & 1,4 & 1,153 & 3 \\
\hline BLML 2 & 5 & 1,3 & 1,156 & 3 \\
\hline BLML 3 & 7,5 & 1,2 & 1,182 & 3 \\
\hline BLML 4 & 10 & 0,7 & 1,165 & 3 \\
\hline
\end{tabular}

Keterangan :

BLML 1: perekat dari getah blendok:air $=1: 3$ dimodifikasi MAH 2,5\% dan BPO 0,75\% dari berat getah blendok

BLML 2: perekat dari getah blendok:air $=1: 3$ dimodifikasi MAH 5\% dan BPO 0,75\% dari berat getah blendok

BLML 3: perekat dari getah blendok:air $=1: 3$ dimodifikasi MAH 7,5\% dan BPO 0,75\% dari berat getah blendok

BLML 4: perekat dari getah blendok:air $=1: 3$ dimodifikasi MAH 10\% dan BPO 0,75\% dari berat getah blendok

Tabel 1 menunjukkan nilai viskositas perekat hasil penelitian, tertinggi adalah 1,4 poise pada perekat BLML 1 kadar MAH 2,5\%. Persyaratan nilai viskositas perekat PVAc menurut SNI 06-6049-1999 adalah minimal 1 poise, sehingga perekat yang sesuai SNI PVAc adalah BLML 1, BLML 2 dan BLML 3. Gambar 2 menunjukkan pengaruh kadar MAH terhadap viskositas perekat, yang mana semakin banyak MAH yang ditambahkan, viskositas semakin kecil.

Viskositas perekat mempengaruhi kemampuan penetrasi perekat dan pembasahan oleh perekat. Semakin kecil viskositas perekat maka semakin besar pula kemampuan perekat untuk mengalir, berpindah dan mengadakan penetrasi serta pembasahan. Hal ini akan semakin meningkatkan kualitas perekatan yang dihasilkan. Tetapi jika viskositas perekat terlalu rendah (encer) akan menyebabkan rendahnya nilai keteguhan rekat. Untuk itu kekentalan harus diatur agar jangan sampai terlalu kental ataupun terlalu encer (Ruhendi, 2000 dalam Widiyanto, 2011)

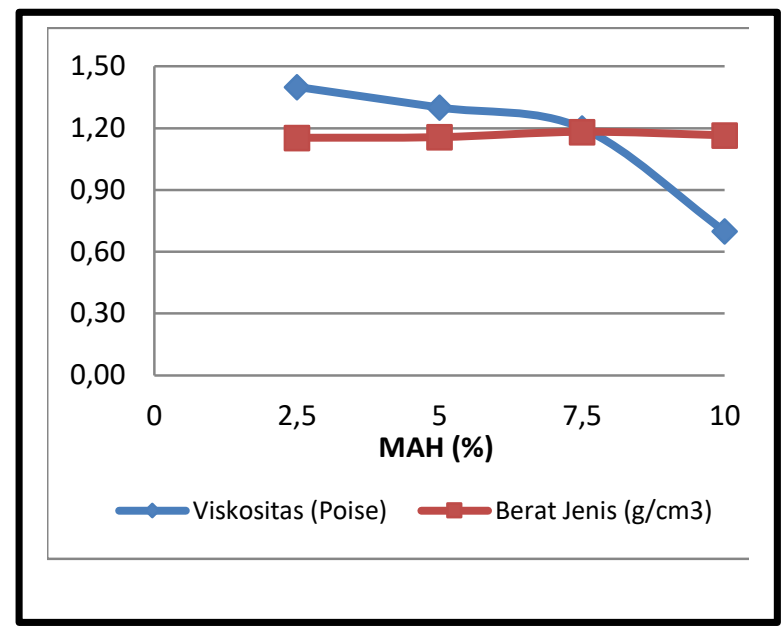

Gambar 2. Pengaruh kadar MAH terhadap viskositas dan berat jenis perekat.

Berat jenis perekat hasil penelitian berkisar antara 1,153-1,182 $\mathrm{g} / \mathrm{cm}^{3}$. Dalam SNI 06-6049-1999 tidak dipersyaratkan nilai berat jenis, namun nilai tersebut mendekati berat jenis yang dipersyaratkan untuk perekat sintetis fenol formaldehida (SNI 06-4567$1998)$ yaitu $1,165-1,200 \mathrm{~g} / \mathrm{cm}^{3}$ (BSN, 1998). Gambar 2 menunjukkan nilai berat jenis perekat getah blendok yang cenderung naik dengan bertambahnya MAH. Hal tersebut sesuai dengan pernyataan Widiyanto (2011), bahwa berat jenis perekat berkaitan erat dengan komponen-komponen penyusun perekat, sehingga semakin banyak komponen perekat yang berat jenisnya tinggi, maka berat jenis perekat akan semakin tinggi pula.

Perekat blendok hasil penelitian mempunyai $\mathrm{pH} 3$, sesuai dengan persyaratan SNI 06-6049-1999 yang berkisar 3-8. Nilai $\mathrm{pH}$ yang rendah akan memperpanjang umur simpan dari perekat tersebut karena bakteri tidak dapat hidup dalam suasana asam (Sulistyanto, dkk, 2015) namun, $\mathrm{pH}$ yang terlalu rendah akan memperlambat proses curing (pengerasan perekat) dan akan merusak kayu atau bahan yang direkatkan (Ruhendi, 2008). 


\section{Sifat-sifat Mekanis Perekat}

Sifat-sifat mekanis perekat diuji setelah perekat diaplikasikan pada bahan kulit kayu jomok, meliputi kuat rekat (peel test) dan delaminasi. Sifat-sifat mekanis perekat blendok ditunjukkan pada Tabel 2 .

Tabel 2. Sifat-sifat mekanis perekat

\begin{tabular}{cccc}
$\begin{array}{c}\text { Jenis } \\
\text { perekat }\end{array}$ & $\begin{array}{c}\text { MAH } \\
\text { (\%) }\end{array}$ & $\begin{array}{c}\text { Kuat rekat } \\
\text { (poise) }\end{array}$ & $\begin{array}{c}\text { Delaminasi } \\
\text { (\%) }\end{array}$ \\
\hline BLML 1 & 2,5 & 0,170 & 0 \\
\hline BLML 2 & 5,0 & 0,070 & 0 \\
\hline BLML 3 & 7,5 & 0,177 & 0 \\
\hline BLML 4 & 10,0 & 0,207 & 0 \\
\hline
\end{tabular}

Kuat rekat perekat sintetis sebagai pembanding adalah sebesar $0,157 \mathrm{~N} / \mathrm{mm}$, sehingga perekat yang memiliki kuat rekat setara perekat sintetis adalah BLML 1, BLML 3 dan BLML 4. Pengaruh kadar MAH terhadap kuat rekat dan delaminasi ditunjukkan pada Gambar 3.

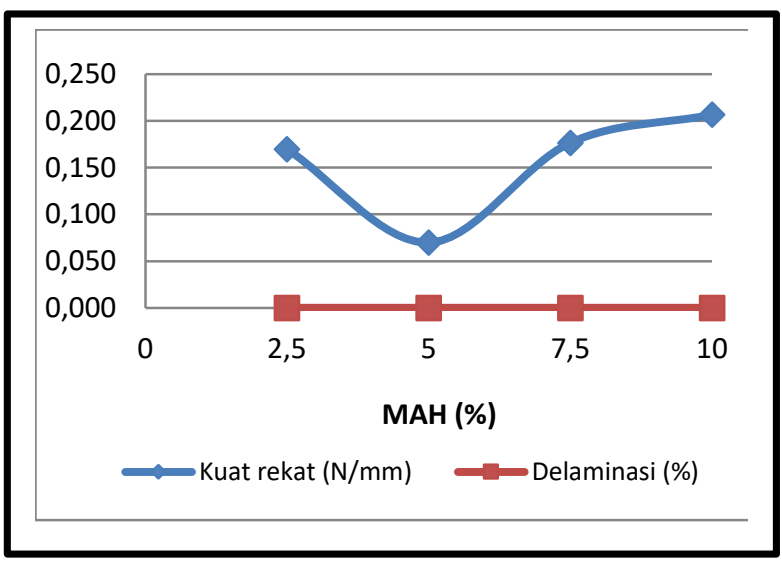

Gambar 3. Pengaruh kadar MAH terhadap kuat rekat dan delaminasi perekat.

Nilai kuat rekat sempat turun pada MAH 5\% namun kemudian naik lagi seiring dengan naiknya kadar MAH. Secara umum penambahan MAH meningkatkan kuat rekat dari perekat blendok, sesuai dengan teori bahwa MAH akan mendorong terjadinya reaksi grafting (pencangkokan) antara perekat dan bahan yang direkat (Febrianto, dkk, 1999).

Nilai delaminasi menunjukkan tingkat kerusakan dari bahan yang direkatkan dengan perekat yang akan diuji. Semakin kecil nilai delaminasi menunjukkan semakin besar daya rekat dari perekat tersebut. Uji delaminasi memiliki ketelitian yang cukup memadai, dapat menyempurnakan metode pengujian serta menentukan kondisi yang tepat untuk penggunaannya di lapangan (Bryant, dkk., 1959 dalam Siruru, 2006).

Tabel 2 menunjukkan nilai delaminasi dari perekat blendok yang diaplikasikan pada bahan kulit kayu Jomok-tripleks. Nilai delaminasi perekat sintetis yang digunakan sebagai pembanding adalah $0 \%$. Pada penelitian ini nilai delaminasi dicapai $0 \%$ pada semua perekat hasil penelitian, menunjukkan tidak adanya kerusakan pada spesimen uji setelah mengalami uji delaminasi.

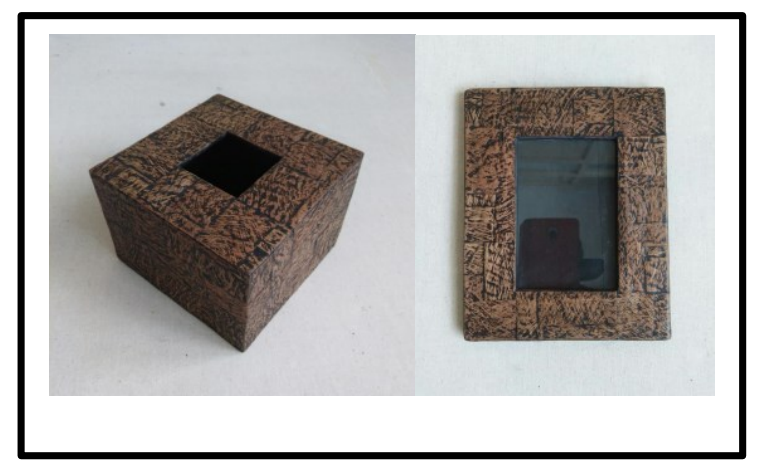

Gambar 4. Produk kerajinan dari kulit kayu Jomok yang direkatkan dengan perekat dari getah blendok.

\section{KESIMPULAN DAN SARAN Kesimpulan}

Sifat-sifat fisis perekat dari getah blendok atau getah pohon Kudo (Lannea coromandelica) yang meliputi viskositas dan pH memenuhi persyaratan SNI 06-60491999 perekat PVAc, sedangkan sifat-sifat mekanisnya yang meliputi kuat rekat dan 
delaminasi, sebanding dengan perekat sintetis yang biasa digunakan di industri kerajinan. Berdasarkan sifat-sifat fisis dan mekanis yang telah dijelaskan maka perekat dari getah blendok atau getah pohon Kudo (Lannea coromandelica) dapat digunakan sebagai alternatif perekat untuk pembuatan barang kerajinan.

\section{Saran}

Perlu dilakukan penelitian lebih lanjut untuk mengetahui kondisi operasi yang optimum pada pembuatan perekat yang dimodifikasi MAH dan BPO serta menjelaskan potensi bahan baku dan nilai ekonomi dari perekat getah blendok.

\section{UCAPAN TERIMAKASIH}

Kami mengucapkan terima kasih kepada Balai Besar Kerajinan dan Batik yang telah memberikan dana sehingga penelitian ini dapat dilakukan. Demikian juga bagi temanteman tim penelitian perekat alami yang telah banyak membantu penelitian ini.

\section{DAFTAR PUSTAKA}

BS. (1994). BS 5350-C12:1994 Methods of Test of Adhesives - Part C12:180 Peel Test for Flexible to Flexible Bonded Assemblies (TPeel Test). London: British Standard Institution (BSI).

BSN. (1998). SNI 06-4567-1998 Fenol Formaldehida Cair untuk Perekat Kayu Lapis. Jakarta, Indonesia: Badan Standarisasi Nasional.

BSN. (1999). SNI 06-6049-1999 Polivinil Asetat Emulsi untuk Perekat Pengerjaan Kayu. Jakarta, Indonesia: Badan Standarisasi Nasional.
BSN. (2006). SNI 01-7201-2006 Kayu Lapis dan Papan Blok Bermuka Kertas Indah. Jakarta, Indonesia: Badan Standarisasi Nasional.

Fathanah, U. (2011). Kualitas Papan Komposit dari Sekam Padi dan Plastik HDPE Daur Ulang Menggunakan Maleic Anhydride (MAH) sebagai Compatibilizer. Jurnal Rekayasa Kimia Dan Lingkungan, 8(2), 53-59.

Febrianto, F., Yoshioka, M., Nagai, Y., Mihara, M., \& Shiraishi, N. (1999). Composite of Wood and trans-1, 4-isoprene rubber 1: Mechanical, physical and flow behavior. Journal of Wood Science, 45(1), 38-45.

Karliati, T. (2014). Karakteristik dan Aplikasi Getah Perca Termodifikasi untuk Perekat Kayu. Disertasi. Institut Pertanian Bogor.

Reddy, A. K. et. al. (2011). Lannea coromandelica: The Researcher' s Tree, Journal of Pharmacy Research 4(3), 577579.

Ruhendi, S. (2008). Kualitas Papan Partikel Kenaf Menggunakan Perekat Likuida dengan Fortifikasi Melamin Formaldehid. Ilmu Dan Teknologi Hasil Hutan, 1(1), 3444.

Siruru, H. (2006). Pengaruh Ekstender dan Bahan Pengisi Perekat Urea Formaldehida Terhadap Delaminasi Papan Blok. Agroforestri, I(3), 19-25.

Sulistyanto, E. P., Darmanto, Y. S., \& Amalia, U. (2015). Karakteristik Lem Ikan dari tiga Jenis Ikan Laut yang Berbeda. Ilmu Dan Kelautan Tropis, 7(1), 23-32.

Widiyanto, A. (2011). Kualitas Papan Partikel Kayu Karet (Hevea brasiliensis Muell. Arg) dan Bambu Tali (Gigantochloa apus Kurz) dengan Perekat Likuida Kayu, Jurnal Penelitian Hasil Hutan, 29(4), 301-311. 